\title{
The Effect of the Natural Sugar Content of Tobacco Upon the Acetaldehyde Concentration found in Cigarette Smoke*
}

\author{
by D. F. Phillpotts, D. Spincer and D. T. Westcott \\ Research Department of Imperial Tobacco Limited, Bristol, England
}

\section{INTRODUCTION}

Braven et al. (1) have shown that acetaldehyde reacts with cysteine. Fenner and Braven (2) also stated that the smoke from flue-cured tobaccos had a larger effect upon the inactivation of cysteine because the larger sugar content of this type of tobacco is responsible for increasing the acetaldehyde content of tobacco smoke.

In the light of these claims we wish to report work carried out in these laboratories on the yield of acetaldehyde from cigarette smoke and its relationship to the sugar content of the tobacco.

\section{EXPERIMENTAL}

Branded cigarettes were not sorted. Experimental cigarettes were made to a constant pressure drop of 6.5-7.5 $\mathrm{cm}$ water. All cigarettes were conditioned in atmospheres held at $60 \% \mathrm{RH}$ and $2 x^{\circ} \mathrm{C}$ for at least 48 hours. The cigarettes were smoked at a puff volume of $35 \mathrm{ml}$ for 2 seconds duration, I pulf per minute. A Phipps and Bird smoking machine was used for the PM (WNF)** deliveries and a Filtrona CSM 10 for the aldehyde determinations. The total volatile aldehydes were determined by a procedure based on the Tobacco Research Council standard method (3). Whole smoke is collected at $-80^{\circ} \mathrm{C}$ and extracted with ethanol. Aldehydes are reacted with 3-methyl-2-benzothiazolone hydrazone hydrodhloride and ferric chloride to give a blue colour. Reaction and colour measurements are performed in a Technicon AutoAnalyzer.

Total sugars are estimated by first hydrolysing them with mineral acid at $95^{\circ} \mathrm{C}$ to give the reducing sugars. These are dialysed, then oxidised with alkaline potassium ferricyanide. The colour loss is measured. Dialysis,

- Received for publication: 10th Januazy, 1974.

* PM (WNF) - Total particulate matter - (water + nicotine). reaction and colour measurements are performed in a Technicon AutoAnalyzer.

\section{RESULTS}

The procedure for the determination of total aldehyde delivery measures aliphatic aldehydes, including formaldehyde and acrolein. From a consideration of the aldehyde composition of cigarette smoke vapour phase given by Newsome et al. (5) and the response of this procedure to various aldehydes investigated by Weaving (6), we conclude that 80 to $85 \%$ of the measured total aldehyde delivery is attributable to acetaldehyde alone.

Table $x$ gives the yields of smoke aldehydes, PM(WNF) and sugar content of some 40 plain and filter cigarettes sold in the United Kingdom market. The sugar contents of these samples range between 14 and $20 \%$ whilst the total aldehyde deliveries vary between $1173 \mu \mathrm{g} / \mathrm{ciga-}$ rette and $2444 \mu \mathrm{g} /$ cigarette. The data in Table 1 were analysed statistically and it was found that neither sugar nor the equilibrium mojsture content of the tobacco was related to aldehyde yield. The only relationship found by us was between aldehyde delivery and PM (WNF) yield; this is expressed by the following equation derived from regression analysis:

Aldehydes $(\mu \mathrm{g} / \mathrm{ctte})=.45.4 \times \mathrm{PM}(\mathrm{WNF})(\mathrm{mg})+836$.

This relationship accounts for $4 x \%$ of the total variation between the 40 United Kingdom brands, which are all of the flue-cured tobacco variety.

Table $z$ is similar to Table $I$ but in this case gives data for brands available in France, West Germany, Belgium, Holland, Italy, Luxembourg, Denmark, Switzerland and Norway. Here the sugar content varies between $I$ and $20 \%$ whilst the aldehyde yield varies between 764 $\mu \mathrm{g} / \mathrm{cigarette}$ to just less than $2000 \mu \mathrm{g} / \mathrm{cigarette}$. 


\begin{tabular}{|c|c|c|c|}
\hline Brand & $\begin{array}{c}\text { PM (WNF)** } \\
\text { mg } \\
\text { at } 20.12 .71\end{array}$ & $\begin{array}{c}\text { Total aldehydes } \\
\text { deliverles } \\
(\mu \mathrm{g} / \mathrm{ctte} .)\end{array}$ & $\begin{array}{c}\text { Sugar } \% \\
\text { (dry basis) }\end{array}$ \\
\hline $1 F$ & 23.3 & 1718 & 17.0 \\
\hline $2 P$ & 26.2 & 1726 & 17.6 \\
\hline $3 \mathrm{~F}$ & 13.0 & 1451 & 15.6 \\
\hline $4 \mathrm{~F}$ & 13.7 & 1353 & 15.9 \\
\hline $5 \mathrm{~F}$ & 17.8 & 1552 & 15.0 \\
\hline $6 P$ & 26.0 & 1857 & 17.0 \\
\hline $7 \mathrm{~F}$ & 22.1 & 1437 & 15.2 \\
\hline $8 \mathrm{~F}$ & 22.6 & 1698 & 14.4 \\
\hline $9 \mathrm{~F}$ & 20.8 & 1400 & 16.5 \\
\hline $10 \mathrm{~F}$ & 23.3 & 1328 & 18.3 \\
\hline $11 P$ & 28.3 & 1965 & 14.5 \\
\hline $12 P$ & 30.6 & 2418 & 18.4 \\
\hline $13 \mathrm{~F}$ & 20.7 & 1837 & 15.8 \\
\hline $14 \mathrm{~F}$ & 23.9 & 1739 & 15.8 \\
\hline $15 F$ & 20.3 & 1627 & 16.4 \\
\hline $16 F$ & 13.1 & 1564 & 19.7 \\
\hline $17 \mathrm{~F}$ & 20.5 & 1550 & 14.5 \\
\hline $18 F$ & 10.3 & 1173 & 18.9 \\
\hline $19 \mathrm{~F}$ & 25.5 & 2444 & 15.7 \\
\hline $20 P$ & 30.5 & 2217 & 18.0 \\
\hline $21 P$ & 27.8 & 2450 & 15.9 \\
\hline $22 \mathrm{~F}$ & 20.3 & 1616 & 16.5 \\
\hline $23 \mathrm{~F}$ & 23.1 & 1998 & 14.9 \\
\hline $24 F$ & 25.0 & 1861 & 17.6 \\
\hline $25 F$ & 22.8 & 2300 & 17.2 \\
\hline $26 \mathrm{~F}$ & 21.6 & 1922 & 16.8 \\
\hline $27 \mathrm{~F}$ & 22.7 & 1823 & 17.7 \\
\hline $28 \mathrm{~F}$ & 27.9 & 2298 & 18.4 \\
\hline $29 \mathrm{~F}$ & 17.0 & 1789 & 17.9 \\
\hline $30 \mathrm{~F}$ & 19.4 & 1740 & 16.7 \\
\hline $31 \mathrm{~F}$ & 22.3 & 1870 & 16.4 \\
\hline $32 \mathrm{~F}$ & 19.3 & 1806 & 16.6 \\
\hline $33 F$ & 20.8 & 1932 & 16.5 \\
\hline $34 \mathrm{~F}$ & 24.1 & 2308 & 16.2 \\
\hline $35 F$ & 16.5 & 1969 & 15.6 \\
\hline $36 \mathrm{~F}$ & 18.3 & 1923 & 14.6 \\
\hline $37 \mathrm{~F}$ & 23.5 & 1690 & 14.5 \\
\hline $38 \mathrm{~F}$ & 23.8 & 1924 & 15.6 \\
\hline $39 \mathrm{~F}$ & 20.5 & 1771 & 14.3 \\
\hline $40 \mathrm{~F}$ & 22.2 & 2323 & 15.8 \\
\hline $41 \mathrm{~F}$ & 18.8 & 2444 & 14.6 \\
\hline $42 \mathrm{~F}$ & 24.1 & 1550 & 16.1 \\
\hline
\end{tabular}

- Some 80-85 \% of these deliveries are due to acetaldehyde. The cigarettes examined were the varleties currently being produced in November 1971. Newer varieties of some of these brands are. currently delivering less total aldehydes due to the use of ventilation techniques etc.

* PM (WNF) = Total particulate matter - (water + nicotine).

F = Filter cigarette $\quad P=$ Plain cigarette

When the data from Continental cigarettes were included in the analyses there was, at first sight, a variation of aldehyde yield with sugar though no relationship with equilibrium moisture. Inspection of the data showed that Italian brands had low sugar and low aldehyde yield, whilst French brands had even lower sugar but higher aldehyde yield.

\begin{tabular}{c|c|c|c}
\hline $\begin{array}{c}\text { Cigarette } \\
\text { brand }\end{array}$ & $\begin{array}{c}\text { PM } \\
(\text { WNF)* } \\
(\mathrm{mg})\end{array}$ & $\begin{array}{c}\text { Total aldehydes } \\
\text { delivery } \\
(\mu \mathrm{g} / \mathrm{ctte})\end{array}$ & $\begin{array}{c}\text { Sugar content } \\
\text { of tobacco } \\
(\% \% \text { dry basis })\end{array}$ \\
\hline
\end{tabular}

France

$\begin{array}{rrrr}1 F & 14.6 & 1423 & 1.9 \\ 2 P & 17.6 & 1966 & 1.4 \\ 3 F & 14.9 & 1632 & 1.2 \\ 4 \text { P } & 15.0 & 1839 & 11.5 \\ 5 P & 15.2 & 1569 & 1.3 \\ 6 F & 11.8 & 1343 & 1.0 \\ 7 F & 20.1 & 1792 & 20.1\end{array}$

West Germany

$\begin{array}{lrrr}\text { 1 F } & 17.4 & 1176 & 12.0 \\ \text { 2 F } & 18.1 & 1779 & 14.2 \\ 3 \text { F } & 16.1 & 1145 & 15.2 \\ 4 \text { F } & 18.0 & 1119 & 12.3 \\ \text { 5 F } & 23.4 & 1042 & 11.7 \\ \text { 6 F } & 19.3 & 1175 & 13.3 \\ \text { 7 P } & 14.7 & 1530 & 9.3 \\ \text { 8 F } & 15.8 & 764 & 10.7 \\ \text { 9 F } & 14.7 & 1335 & 10.4\end{array}$

Belgium

$\begin{array}{lllr}1 F & 14.8 & 1633 & 10.0 \\ 2 P & 12.8 & 1644 & 4.0 \\ 3 F & 15.5 & 1658 & 17.0\end{array}$

Holland

$\begin{array}{llll}1 \mathrm{~F} & 16.7 & 1567 & 16.7 \\ \text { 2 F } & 13.2 & 1522 & 10.1 \\ \text { 3 P } & 14.3 & 1386 & 11.9 \\ 4 \mathrm{~F} & 13.4 & 1459 & 13.0 \\ \text { 5 F } & 12.7 & 1380 & 1.0 .8 \\ \text { 6 P } & 16.6 & 1510 & 12.5 \\ 7 \mathrm{~F} & 13.5 & 1527 & 14.6\end{array}$

Italy

$\begin{array}{llll}1 P & 18.3 & 943 & 8.1\end{array}$

$\begin{array}{llll}2 F & 18.4 & 1009 & 5.2\end{array}$

$\begin{array}{llll}3 F & 19.4 & 895 & 4.3\end{array}$

$\begin{array}{llll}4 P & 18.7 & 1397 & 5.4\end{array}$

$\begin{array}{llll}5 F & 19.8 & 921 & 4.5\end{array}$

$\begin{array}{lllr}6 P & 14.3 & 1117 & 2.0\end{array}$

$\begin{array}{llll}7 F & 15.9 & 1153 & 10.9\end{array}$

Luxembourg

$\begin{array}{llll}1 \mathrm{~F} & 16.1 & 1352 & 12.4\end{array}$

Denmark

$\begin{array}{rrrr}1 P & 14.8 & 1600 & 13.2 \\ 2 F & 13.9 & 1653 & 9.0 \\ 3 P & 14.3 & 1455 & 10.9 \\ 4 P & 13.4 & 1226 & 8.1\end{array}$

Switzerland

$\begin{array}{llll}1 \mathrm{~F} & 14.6 & 964 & 10.0\end{array}$

Norway

$\begin{array}{llll}1 P & 15.4 & 1142 & 12.0\end{array}$

- $P M(W N F)=$ Total particulate matter $-($ water + nicotine $)$. 


\begin{tabular}{l|c|c|c}
\hline $\begin{array}{c}\text { Tobacco type } \\
\text { (single grades) }\end{array}$ & $\begin{array}{c}\text { PM } \\
\text { (WNF)* } \\
\text { (mg) }\end{array}$ & $\begin{array}{c}\text { Total } \\
\text { aldehydes } \\
\text { delivery } \\
(\mu \mathrm{g} / \mathrm{ctte})\end{array}$ & $\begin{array}{c}\text { Sugar content } \\
\text { (\%) dry basis) }\end{array}$ \\
\hline Sun-cured & 41.7 & 1310 & 2.8 \\
Flre-cured & 40.6 & 1005 & 2.9 \\
Alr-cured/Burley & 24.9 & 1193 & 1.8 \\
Flue-cured & 31.6 & 1465 & 9.2 \\
Flue-cured & 28.5 & 978 & 16.3 \\
Flue-cured & 34.4 & 1438 & 28.6 \\
\hline
\end{tabular}

- PM $(W N F)=$ Total particulate matter $-($ water + nicotine $)$.

It was therefore thought that Italian brands showed this low aldehyde yield because of some other property and not its low sugar content. $A$ separate statistical analysis was made which allowed for differences between the Italian brands and other brands, and it was found that this explained all the differences and no other relationship with sugar content remained. The relationship was shown to be

Aldehydes $(\mu \mathrm{g} / \mathrm{ctte})=.42 \times \mathrm{PM}(\mathrm{WNF})(\mathrm{mg})+84 \mathrm{I}$

for all but the Italian cigarettes and also that

Aldehydes $(\mu \mathrm{g} / \mathrm{ctte})=.42 \times \mathrm{PM}(\mathrm{WNF})(\mathrm{mg})+320$

for Italian cigarettes.

Table 3 lists the values for total aldehyde delivery obtained from plain cigarettes manufactured from single grades of tobacco. It is evident from inspection of the results that there is no correlation between aldehyde and sugar content for these cigarettes.

\section{DISCUSSION}

Fenner and Braven (2) claim that cigarettes made from flue-cured tobacco deliver some 50\% more acetaldehyde than similar products made from air-cured tobaccos. Furthermore these workers (2) have shown that glucose pyrolysed at between $300-360^{\circ} \mathrm{C}$ produces significant quantities of acetaldehyde.

It is known that sugar pyrolysed during the smoking process does yield some acetaldehyde but that this is the major source of acetaldehyde is in dispute. Dawson (4) claimed that acetaldehyde is produced at levels below those of carbon monoxide and acetone and that only $2 \%$ of the sugar ends up as mixed pyrolysis products.

The results of our experiments show that the total aldehyde yield in smoke is not related to the natural sugar content of the tobacco. It is appreciated that the effects of filtration and weights of tobacco burned have not been taken into account, but with such very large differences in sugar content between samples it was felt that any relationship that existed would nevertheless show up. To postulate that the yield of acetaldehyde depends on the sugar content would require a hypothesis which could account for a tobacco with $1 \%$ sugar yielding an equivalent amount of aldehyde to one with $20 \%$ sugar.

The correlation of $41 \%$ between PM(WNF) and aldehydes suggests that the aldehydes delivery is largely influenced by such factors as filtration, ventilation and burning rate which normally affect yields of smoke components.

The extrapolation of data obtained in non-smoking experiments neglects such factors and can often give rise to misleading conclusions.

\section{CONCLUSIONS and SUMMARY}

All the evidence obtained in our laboratories has shown that the total aldehyde yield in tobacco smoke is not related to either sugar content or the equilibrium moisture content of the tobaccos.

There is, however, a relationship between particulate matter $[\mathrm{PM}(\mathrm{WNF})]^{*}$ and aldehyde delivery. This accounts for some $41 \%$ of the total variation between different cigarettes.

\section{SCHLUSSFOLGERUNGEN und ZUSAMMENFASSUNG}

Auf Grund eigener Experimente weisen die Autoren nach, daß die Ausbeute an Gesamtaldehyden im Tabakrauch weder $z u$ dem Zuckergehalt des Tabaks noch $z u$ dessen Gleichgewichtsfeuchte in Beziehung steht.

Es besteht jedoch eine Beziehung zwischen der Ausbeute an trockenem Rauchkondensat (abzüglich Nikotin) und der an Aldehyden. Hierauf beruhen etwa 4. $\%$ der gesamten Unterschiede zwischen verschiedenen Cigaretten.

\section{CONCLUSIONS et RESUME}

Toutes les preuves qui ont été obtenues dans nos laboratoires montrent que le rendement en aldéhydes totaux dans la fumée de cigarettes est indépendant de la teneur en sucre des tabacs ou de leur humidité d'équilibre.

Il y a par contre une relation entre le condensat sec (moins la nicotine) et la production d'aldéhydes. Ceci représente $41 \%$ du total des variations entre les différentes cigarettes.

\footnotetext{
- PM $($ WNF $)=$ Total particulate matter $-($ water + nicotine $)$.
} 


\section{REFERENCES}

x. Braven, J., G. J. Bonker, M. L. Fenner and B. L. Tonge: Brit. J. Cancer 21 (3) (1967) 623.

2. Fenner, M. L., and J. Braven: Brit. J. Cancer 22 (3) (1968) 474.

3. Tobacco Research Council, London: Research Paper No. 11.

4. Dawson, R. F., R. D. Carpenter, F. L. Gager, R. W. Jenkins and R. H. Newman: Proceedings of the 5 th International Tob. Sci, Congress, Hamburg, 1970, 245.

5. Newsome, J. R., V. Norman and C. H. Keith: Tobacco Sci. 9 (1965) 102.
6. Weaving, A. S.: 1gth Tobacco Chemists' Research Conference, Lexington, Kentudky, U.S.A., October 1965.

\section{Adknowledgement}

The authors wish to thank their colleague Mr. W. S. Paige for his help and advice in carrying out the statistical analysis.

The authors' address:

Imperial Tobacco Limited, Research Department, Raleigh Road, Bristol, BS 3 1QX, England. 